\title{
New insights on resource stoichiometry: assessing availability of carbon, nitrogen, and phosphorus to bacterioplankton
}

\author{
Ana R. A. Soares ${ }^{1}$, Ann-Kristin Bergström ${ }^{2}$, Ryan A. Sponseller ${ }^{2}$, Joanna M. Moberg ${ }^{1}$, Reiner Giesler ${ }^{4}$, \\ Emma S. Kritzberg ${ }^{3}$, Mats Jansson ${ }^{2}$, and Martin Berggren ${ }^{1}$ \\ ${ }^{1}$ Department of Physical Geography and Ecosystem Science, Lund University, Lund, 22362, Sweden \\ ${ }^{2}$ Department of Ecology and Environmental Science, Umeå University, Umeå, 90187, Sweden \\ ${ }^{3}$ Department of Biology/Aquatic Ecology, Lund University, Lund, 22362, Sweden \\ ${ }^{4}$ Climate Impacts Research Centre, Department of Ecology and Environmental Science, Umeå University, \\ 98107 Abisko, Sweden
}

Correspondence to: Ana R. A. Soares (anaralvessoares@gmail.com)

Received: 16 October 2016 - Discussion started: 1 November 2016

Revised: 24 February 2017 - Accepted: 2 March 2017 - Published: 24 March 2017

\begin{abstract}
Boreal lake and river ecosystems receive large quantities of organic nutrients and carbon $(\mathrm{C})$ from their catchments. How bacterioplankton respond to these inputs is not well understood, in part because we base our understanding and predictions on "total pools", yet we know little about the stoichiometry of bioavailable elements within organic matter. We designed bioassays with the purpose of exhausting the pools of readily bioavailable dissolved organic carbon (BDOC), bioavailable dissolved nitrogen (BDN), and bioavailable dissolved phosphorus (BDP) as fast as possible. Applying the method in four boreal lakes at base-flow conditions yielded concentrations of bioavailable resources in the range $105-693 \mu \mathrm{g} \mathrm{CL}^{-1}$ for BDOC ( $2 \%$ of initial total DOC), 24-288 $\mu \mathrm{g} \mathrm{NL}^{-1}$ for BDN (31\% of initial total dissolved nitrogen), and $0.2-17 \mu \mathrm{g} \mathrm{PL}^{-1}$ for BDP (49\% of initial total dissolved phosphorus). Thus, relative bioavailability increased from carbon (C) to nitrogen $(\mathrm{N})$ to phosphorus $(\mathrm{P})$. We show that the main fraction of bioavailable nutrients is organic, representing $80 \%$ of BDN and $61 \%$ of BDP. In addition, we demonstrate that total $\mathrm{C}: \mathrm{N}$ and $\mathrm{C}: \mathrm{P}$ ratios are as much as 13 -fold higher than $\mathrm{C}: \mathrm{N}$ and $\mathrm{C}: \mathrm{P}$ ratios for bioavailable resource fractions. Further, by applying additional bioavailability measurements to seven widely distributed rivers, we provide support for a general pattern of relatively high bioavailability of $\mathrm{P}$ and $\mathrm{N}$ in relation to $\mathrm{C}$. Altogether, our findings underscore the poor availability of $\mathrm{C}$ for support of bacterial metabolism in boreal C-rich fresh-
\end{abstract}

waters, and suggest that these ecosystems are very sensitive to increased input of bioavailable DOC.

\section{Introduction}

Nutrient regulation of freshwater plankton productivity is central to the response of river and lake ecosystems to changes in nutrient loading that result from land use and climate change. By controlling phytoplankton primary production (PP) and bacterioplankton secondary production (BP), phosphorus $(\mathrm{P})$ and nitrogen $(\mathrm{N})$ are the two key macronutrients shaping aquatic ecosystems, with consequences for food web structure, biodiversity, and biogeochemical cycles (Jones, 1998). In addition to these nutrients, the supply of dissolved organic carbon (DOC) has strong effects on ecosystem functioning by fuelling BP and bacterial-based heterotrophic food chains (Dillon and Molot, 2005; Karlsson et al., 2012; Tranvik, 1998). While nutrient availability can be influenced by internal lake processes, the regulation of PP and BP in the majority of lakes worldwide is constrained by loading of inorganic and organic resources from the surrounding terrestrial landscape (Wetzel, 2001). In brown-water boreal lakes, nutrients bound to dissolved organic matter (DOM) (e.g. humic substances) often dominate inputs (Jansson, 1998). In such systems, terrestrial nutrient support of BP is of particular ecological and biogeochemical 
importance, as heterotrophic processes often greatly exceed autotrophy (Jansson et al., 2000).

While the importance of nutrient availability at the ecosystem level is evident, characterisations of the actual proportion of terrestrially derived resources that can be readily used by aquatic microorganisms are difficult and attempts to characterise it are rare. A variable fraction of $\mathrm{C}, \mathrm{N}$, and $\mathrm{P}$ of terrestrial origin is chemically bound in organic molecules that are typically too large to be directly taken up by microbes (Battin et al., 2008). The nature of the covalent bonds and the structure of organic compounds that hold $\mathrm{N}$ and $\mathrm{P}$ also differentially influence the bioavailability and turnover of associated nutrients (Vitousek et al., 2002). Such complexity makes it difficult to predict the potential for bacterial usage of these resources in an ecologically meaningful way (Bronk et al., 2007; Berggren et al., 2015; Helton et al., 2015). It is generally thought that the major fraction of DOC originating from terrestrial soils is recalcitrant, yet bioavailability estimates from different lakes suggest that a variable proportion of DOC can be used by bacteria (e.g. 6-14\%; Tranvik, 1988). For dissolved organic nitrogen (DON), a summary of published assays suggests that anywhere from 2 to $75 \%$ of the organic N pool may be bioavailable (Pellerin et al., 2006), with a range of 19-28\% reported for boreal streams during base flow (Stepanauskas et al., 1999). Similarly, while less studied, $\mathrm{P}$ bioavailability appears to be highly variable over space and time (Muscarella et al., 2014). For example, it has been shown that seasonal concentrations of bioavailable $\mathrm{P}$ ranged from 1 to $14 \mu \mathrm{gL}^{-1}$ in boreal headwater streams, representing from $<5 \%$ to nearly $50 \%$ of the total $\mathrm{P}$ pool (Jansson et al., 2012). Most studies on nutrient availability conducted in humic-rich waters have neglected this variability in bioavailability, focusing on either total inputs (i.e. total $\mathrm{N}$ or total $\mathrm{P}$ ) or on the turnover of specific fractions assumed to be bioavailable (e.g. dissolved inorganic nitrogen, DIN; molybdate reactive phosphorus, MRP). However, inorganic fractions may constitute only a small part of the total nutrient pools and can underestimate resource bioavailability in organic-rich waters with large pools of labile DON or dissolved organic phosphorus (DOP; Seitzinger et al., 2002).

These pitfalls of assuming resource availability to bacterioplankton from total pools or inorganic fractions have prompted the suggestion that standardised bioavailability assays (growth bioassays) should be incorporated into the analytical toolbox of aquatic researchers (Lewis Jr., 2011). Bioavailability represents an operationally defined resource, typically measured in assays in which a bacterial inoculum is added to a sterile-filtered water sample and the bacterial biomass is allowed to grow during a standardised incubation period at a determined temperature. The growth response is used to quantify the resource that was consumed during the incubation, which is a measure of bioavailability (sensu Berggren et al., 2015).Unfortunately results from the few different studies addressing bioavailable resource shares for bacterioplankton are difficult to compare since different methodological approaches are used (Berggren et al., 2015). For instance, studies of DOC bioavailability have used methods that differ in terms of incubation length, temperature, as well as the choices of inoculum and inorganic growth media (del Giorgio and Davis, 2003). Similarly, as different techniques and assumptions have been applied to assess nutrient availability, results for $\mathrm{N}$ and $\mathrm{P}$ differ among studies and are generally not comparable as they often reflect variation in experimental factors rather than in the intrinsic molecular properties of the nutrients themselves. Thus, a standard and comparable method that can tackle the bioavailability of multiple elements to bacterioplankton is missing.

Most previous attempts to measure nutrient bioavailability of multiple elements have been performed over very long timescales (most data from 100-day incubations; see data review by Lonborg and Anton Alvarez-Salgado, 2012) and do not represent the pool that is immediately available for consumption. These long-term assays have not been based on growth, but on changes in bulk nutrient concentrations in solution (Lonborg and Anton Alvarez-Salgado, 2012). However, during long incubation periods various factors can interfere with the uptake of bioavailable resources, such as the dynamics of viruses and the development of toxic conditions that may arise from repeated bacterial regeneration of resources (Cho et al., 1996). To move the nutrient stoichiometry field forward, a promising option is to measure the uptake of nutrients through growth bioassays conducted at shorter timescales, in which the incubation length is reduced to a minimum and sufficient time for bacteria to take up most of the readily bioavailable pool (sensu Berggren et al., 2015). Such bioassays can increase our understanding of the direct controls on bacterial metabolism by bioavailable nutrient pools. Although growth bioassays have previously been applied to calculate bioavailability of single elements (Stepanauskas et al., 2000, 2002; Jansson et al., 2012), no efforts to date have quantified the bioavailability of more than two elements simultaneously so that the relative availability of multiple resources can be directly compared. In a recent review on bioavailability (Berggren et al., 2015), it was additionally suggested that nutrient bioavailability (as a fraction of the total pool) tends to increase from $\mathrm{C}$ to $\mathrm{N}$ and $\mathrm{N}$ to $\mathrm{P}$ in DOM-rich systems. While this hypothesis is generally consistent with our understanding of resource use in soils ( $\mathrm{Vi-}$ tousek et al., 2002), it remains to be systematically tested in surface waters.

In this study, we designed bioassays with the purpose of rapidly exhausting the pools of readily available organic $\mathrm{C}$, $\mathrm{N}$, and $\mathrm{P}$ that are accessible to bacterioplankton in DOMrich lakes. The bioassays were designed such that most of the nutrients were used within 3 days, although we measured the cumulative nutrient use up to 7 days. We first calibrated our method by detecting the response (leucine incorporation) of nutrient-starved bacteria to known added amounts of bioavailable resources. We then validated this bacterial response through comparison with common methods to detect 
Table 1. Descriptive lake data and concentrations of total dissolved nitrogen (TDN), dissolved inorganic nitrogen (DIN), total phosphorus (TP), phosphate $\left(\mathrm{PO}_{4}-\mathrm{P}\right)$, and dissolved organic carbon (DOC) given as minimum and maximum values observed during the experimental period.

\begin{tabular}{lrrrr}
\hline Variables & Övre Björntjärnen & Lillsjöliden & Struptjärnen & Stortjärnen \\
\hline Location (latitude [N], & $64^{\circ} 7^{\prime} 23.53^{\prime \prime} \mathrm{N}$, & $63^{\circ} 50^{\prime} 41.71^{\prime \prime} \mathrm{N}$, & $64^{\circ} 1^{\prime} 22.62^{\prime \prime} \mathrm{N}$, & $64^{\circ} 15^{\prime} 42.11^{\prime \prime} \mathrm{N}$, \\
longitude [E]) & $18^{\circ} 46^{\prime} 43.04^{\prime \prime} \mathrm{E}$ & $18^{\circ} 36^{\prime} 59.62^{\prime \prime} \mathrm{E}$ & $19^{\circ} 29^{\prime} 21.18^{\prime \prime} \mathrm{E}$ & $19^{\circ} 45^{\prime} 44.73^{\prime \prime} \mathrm{E}$ \\
\hline Lake surface area (ha) & 4.8 & 0.8 & 3.1 & 3.9 \\
Maximal depth (m) & 9.5 & 5.2 & 5.8 & 6.7 \\
Total catchment area (ha) & 284 & 25 & 79 & 82 \\
Wetland coverage (\%) & 16 & 2 & 4 & 12 \\
Forest coverage (\%) & 84 & 98 & 96 & 88 \\
DOC (mg L $\left.{ }^{-1}\right)$ & $18-29$ & $13-19$ & $19-25$ & $19-27$ \\
TDN $\left(\mu \mathrm{g} \mathrm{L}^{-1}\right)$ & $376-502$ & $36-501$ & $360-521$ & $355-598$ \\
DIN $\left(\mu \mathrm{g} \mathrm{L}^{-1}\right)$ & $5-35$ & $10-40$ & $3-43$ & $4-35$ \\
$\mathrm{TP}\left(\mu \mathrm{g} \mathrm{L}^{-1}\right)$ & $8-25$ & $4-15$ & $8-25$ & $7-15$ \\
$\mathrm{PO}_{4}-\mathrm{P}\left(\mu \mathrm{g} \mathrm{L}^{-1}\right)$ & $1-8$ & $0-4$ & $0-3$ & $0-2$ \\
\hline
\end{tabular}

bioavailability: lability incubations for DOC bioavailability (del Giorgio and Cole, 1998), cell production bioassays with $\mathrm{N}$-starved bacteria for $\mathrm{N}$ bioavailability (Stepanauskas et al., 2000) and measuring P content in bacterial growth cultures harvested on filters (Jansson et al., 2012). Specifically, by using this new bacterioplankton growth bioassay, our study addresses the following questions. (1) How does the relative total bioavailability in DOM-rich surface waters differ between the elements, i.e. bioavailable dissolved organic carbon (BDOC) out of total DOC, bioavailable dissolved nitrogen (BDN) out of total $\mathrm{N}$, and bioavailable dissolved phosphorus (BDP) out of total $\mathrm{P}$, and do these proportions vary seasonally? (2) Are the organic bioavailable $\mathrm{N}$ and $\mathrm{P}$ pools larger than the corresponding inorganic pools? (3) By how much do total $\mathrm{C}: \mathrm{N}, \mathrm{C}: \mathrm{P}$ and $\mathrm{N}: \mathrm{P}$ ratios exceed bioavailable $\mathrm{C}: \mathrm{N}, \mathrm{C}: \mathrm{P}$ and $\mathrm{N}: \mathrm{P}$ ? This was tested by performing bacterial growth bioassays on four boreal lakes in northern Sweden with high DOM concentrations. In addition, we applied a simplified version of our new method to assess broad patterns in nutrient bioavailability across a larger cross-regional scale and climate gradient that comprises seven river systems with variable DOM concentrations.

\section{Methods}

\subsection{Study area and sampling}

We studied four lakes in northern boreal Sweden: Övre Björntjärnen, Lillsjöliden, Struptjärnen and Stortjärnen. All lakes are unproductive brown-water systems of similar size and morphology (Table 1). Lake catchments are dominated by coniferous forest (Scots Pine, Pinus sylvestris; Norway spruce, Picea abies); and wetlands (mires) in different proportions. The lakes are closely co-located (maximum distance $75 \mathrm{~km}$ ) and influenced by similar climatic conditions.
Average annual temperature, precipitation, and run-off in this area are approximately $1.8^{\circ} \mathrm{C}, 614$, and $311 \mathrm{~mm}$ respectively (from 1981 to 2010; Laudon et al., 2013). Lake surface ice coverage extends from November to May; stratification occurs during late May/early June and mixing occurs after midSeptember.

In addition to these lakes, we also sampled the outlet of seven Swedish rivers (Lyckebeån, Helge å, Nyköpingsån, Motala Ström, Torne älv, Töre älv, Öre älv) that drain into the Baltic Sea. River catchments are located between latitudes 55 and $65^{\circ} \mathrm{N}$, falling along a $1300 \mathrm{~km}$ north-south gradient, spanning a range of drainage areas of $440-34441 \mathrm{~km}^{2}$, and with DOC concentrations from 5.6 to $23 \mathrm{mg} \mathrm{L}^{-1}$. These rivers drain very different terrestrial environments from mountains, forests, and wetlands in the north to catchments with a significant fraction of agricultural land and urban development in the south (Sponseller et al., 2014). In addition, these systems are influenced by different climates, from subarctic in the north to temperate in the south. From north to south, average temperature, precipitation, and discharge respectively span from 1 to $8{ }^{\circ} \mathrm{C}, 631$ to $824 \mathrm{~mm}$, and 34 to $450 \mathrm{~m}^{3} \mathrm{~s}^{-1}$ (for 1999-2013; Swedish Meteorological and Hydrological Institute, SMHI).

Lake samples $(2 \mathrm{~L})$ were collected from $0.5 \mathrm{~m}$ depth on seven dates from September 2012 to September 2014 (Table 2). Samples were stored in acid-washed $2 \mathrm{~L}$ high-density polyethylene bottles or $4 \mathrm{~L}$ low-density polyethylene containers (Thermo Scientific) in the dark at approximately $1{ }^{\circ} \mathrm{C}$ until arrival at the laboratory. River sampling was conducted once at the outlet of each river between June and July 2013 at $0.3 \mathrm{~m}$ depth, in the middle of the river or $7 \mathrm{~m}$ from the shore.

\subsection{Determination of bioavailable $\mathrm{C}, \mathrm{N}$, and $\mathrm{P}$}

To determine concentrations of BDOC, BDN, and BDP we conducted growth bioassays in which the limitation of either 


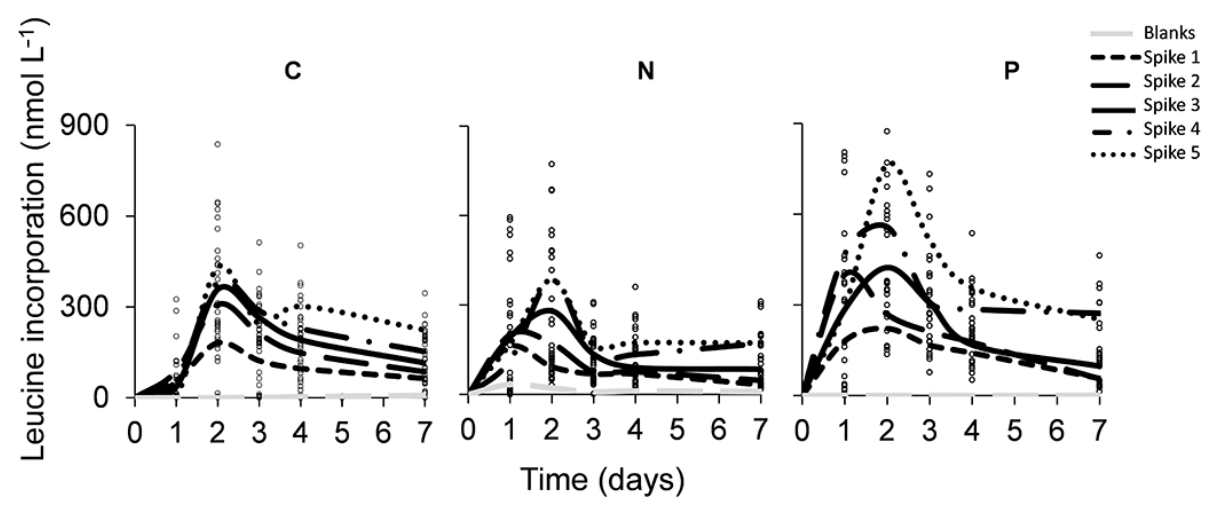

Figure 1. Leucine incorporation rates over the incubation time for a blank incubation and five spikes of $\mathrm{C}$ (spike $1=330$, spike $2=660$, spike $3=1000$, spike $4=1330$, and spike $5=1500 \mu \mathrm{g} \mathrm{C} \mathrm{L}^{-1}$ ), $\mathrm{N}$ (spike $1=105$, spike $2=133$, spike $3=205$, spike $4=305$ and spike $5=405 \mu \mathrm{g} \mathrm{NL}^{-1}$ ) and $\mathrm{P}$ (blank, spike $1=15.5$, spike $2=18.8$, spike $3=20.5$, spike $4=30.5$, and spike $5=40.5 \mu \mathrm{gL}^{-1}$ ).

$\mathrm{C}, \mathrm{N}$, or $\mathrm{P}$ was strongly induced by adding different combinations of bacterial growth media. Our growth bioassays were designed so that resource use efficiency was at its maximum and bacterial production would occur mostly within 3 days from the beginning of the experiment. The bacterial response to those bioassays was measured by leucine incorporation (Kirchman et al., 1985). The amount of leucine incorporated in each bioassay was then converted into concentrations of bioavailable resource based on experimentally determined standard growth curves (see detailed description below).

Bioassays were prepared immediately after or at latest within 1 to 2 weeks after sampling. To ensure proper conservation of the samples prior to the experiment, they were immediately filtered (Whatman GF/F) and stored in a climatecontrolled chamber at a temperature close to $1^{\circ} \mathrm{C}$. At the initiation of the experiment, $500 \mathrm{~mL}$ of each lake and river water sample was again filtered at $0.2 \mu \mathrm{m}$ (suporCap 100, Gelman Sciences) and placed in a $1000 \mathrm{~mL}$ Erlenmeyer flask. All bioassay samples were then inoculated with a standard bacterial community $2 \%(v / v)$ to ensure that differences in bacterial community composition did not influence resource bioavailability measurements (Martinez et al., 1996). The standard bacterial community consisted of a mixture of fresh unfiltered water from the epilimnion and inlet of the lakes sampled at one occasion, which was maintained in the fridge at $4{ }^{\circ} \mathrm{C}$ between experiments. The water was amended $5 \%(v / v)$ with a modified (excluding $\mathrm{C}, \mathrm{N}$, and $\mathrm{P}$ ) bacterial medium ("L16"; Lindström, 1991) rich in micronutrients, trace metals, and vitamins required for bacterial growth. The sample was then divided into three subvolumes to which strong limitation of either $\mathrm{C}, \mathrm{N}$ or $\mathrm{P}$ was induced by adding appropriate combinations of nutrients. $\mathrm{C}$ limitation was induced by adding $\mathrm{N}$ as $\mathrm{NH}_{4} \mathrm{NO}_{3}$ (final concentration $\left.2000 \mu \mathrm{g} \mathrm{NL} \mathrm{N}^{-1}\right)$ and $\mathrm{P}$ as $\mathrm{Na}_{2} \mathrm{HPO}_{4}\left(200 \mu \mathrm{g} \mathrm{PL}^{-1}\right)$. Nlimiting conditions were created by adding $\mathrm{C}$ as $\mathrm{C}_{6} \mathrm{H}_{12} \mathrm{O}_{6}$ $\left(20000 \mu \mathrm{CL}^{-1}\right)$ and $\mathrm{P}$ as $\mathrm{Na}_{2} \mathrm{HPO}_{4}\left(200 \mu \mathrm{g} \mathrm{PL}{ }^{-1}\right)$. P- limiting conditions were created by adding $\mathrm{C}$ as $\mathrm{C}_{6} \mathrm{H}_{12} \mathrm{O}_{6}$ $\left(20000 \mu \mathrm{g} \mathrm{L}^{-1}\right)$ and $\mathrm{N}^{2} \mathrm{NH}_{4} \mathrm{NO}_{3}\left(2000 \mu \mathrm{g} \mathrm{NL}^{-1}\right)$. Samples were then transferred into $1.5 \mathrm{~mL}$ Eppendorf tubes that were incubated in the dark at the standard temperature of $20^{\circ} \mathrm{C}$, which is the most broadly applied temperature in bioavailability assessments of the literature (del Giorgio and Davis, 2003). For each bioassay incubation, leucine incorporation was measured at six time points (after $0,1,2,2,3$, and 7 days) on five replicate samples each time. The inoculum added to our sample water represents an unknown addition of bioavailable $\mathrm{C}, \mathrm{N}$, and $\mathrm{P}$. To ensure that the amount of resource added through inoculation was insignificant, we analysed five control bioassay replicates in which the only source of $\mathrm{C}, \mathrm{N}$, or $\mathrm{P}$ was the amount of resource contained in the inoculum and thus the lake sample was replaced by MiliQ water. All such control bioassays resulted in low amounts of leucine uptake (Fig. 1), which was then used to correct our estimates of resource bioavailability through subtraction (see Supplement Table S2).

To create standard curves for bacterial growth per unit limiting nutrient, sampled lake water from September 2012 was used to perform a bioassay following the approach described above but with varying concentration of target elements. For example, to a subvolume that was induced to be C-limited, $\mathrm{C}_{6} \mathrm{H}_{12} \mathrm{O}_{6}$ was added to final concentrations of 330,660 , 1000,1330 , and $1500 \mu \mathrm{g} \mathrm{CL}{ }^{-1}$ respectively. The response to each concentration was measured on triplicate samples and was used to construct the standard curve. The same procedure was applied to produce standard curves for $\mathrm{N}$ and $\mathrm{P}$ limited assays. $\mathrm{NH}_{4} \mathrm{NO}_{3}$ was added to concentrations of 105 , 133, 205, 305, $405 \mu \mathrm{g} \mathrm{NL}{ }^{-1}$, and $\mathrm{Na}_{2} \mathrm{HPO}_{4}$ was added to concentrations of $15.5,18.8,20.5,30.5,40.5 \mu \mathrm{g} \mathrm{PL}{ }^{-1}$ (see Supplement Table S1). Standard curves for the rivers were based on the same method but bacterial responses to each concentration were recorded once.

Integrated (cumulative) amounts of leucine incorporated by bacteria during lake or river bioassays over 7 days were 
converted to concentrations of bioavailable element based on the slopes of the standard growth curves of either rivers or lakes, which describe how much leucine was incorporated per unit of bioavailable limiting element. For this conversion, the amount of incorporated leucine (given in nmol of leucine $\mathrm{L}^{-1}$ for 7 days) during each bioassay was divided by the slope of the standard growth curve (nmol of leucine $\mathrm{L}^{-1}$ per mg of bioavailable nutrient $\mathrm{L}^{-1}$ for 7 days). The resulting quotient represents the total amount of bioavailable nutrient taken up by bacterioplankton $\left(\mathrm{mg} \mathrm{L}^{-1}\right.$ for 7 days; see Supplement Table S3).

\subsection{Leucine incorporation}

Measurements of protein synthesis were done using the method described by Smith and Azam (1992) and modified by Karlsson et al. (2002). Accordingly, ${ }^{3} \mathrm{H}$-leucine was added to sample water in Eppendorf tubes (specific activity varied between 60.5 and $115.8 \mathrm{Ci} \mathrm{mmol}^{-1}$, Perkin Elmer) with a final concentration of $30-100 \mathrm{nmol} \mathrm{L}^{-1}$. Additions of ${ }^{3} \mathrm{H}$-leucine were dependent on bacterial activity tests performed prior to the experiments in which different concentrations of ${ }^{3} \mathrm{H}$-leucine identified the isotope saturation levels. Triplicate measurements were taken after 24, 48 (we obtained six replicates at this time point), 72, 96 and $168 \mathrm{~h}$. Leucine incorporation into protein was determined by incubation for $1 \mathrm{~h}$ in the dark at $20^{\circ} \mathrm{C}$ and incubations were terminated with trichloroacetic acid (TCA) additions of $5 \%$ $(w / v)$. A bacterial pellet was formed by centrifugation for $10 \mathrm{~min}$ at $14000 \mathrm{rpm}$. The bacterial pellet was rinsed with $5 \%$ TCA. After the addition of $1.2 \mathrm{~mL}$ of scintillation cocktail (PerkinElmer), radioactivity was measured on a Wallac WinSpectral 1414 Scintillation counter (PerkinElmer). The incorporation of ${ }^{3} \mathrm{H}$-leucine was calculated using an intracellular dilution factor of 2 (Smith and Azam, 1992). Leucine incorporation measurements were integrated for the six time points and summed into a single value that represented the total amount of leucine incorporated for the 7-day period. Lastly, at time point $96 \mathrm{~h}$, an extra vial was collected and used as a blank, pretreated with TCA $5 \%(w / v)$, followed by the addition of leucine at a final concentration of $30 \mathrm{nmol} \mathrm{L}^{-1}$.

\subsection{Validation}

We validated the bacterial leucine uptake response to added amounts of BDOC, BDN, and BDP (i.e. the slope of the standard curves) by relating the measured leucine uptake to alternative estimates of bioavailable resources obtained with independent methods. An alternative estimate of BDOC was obtained from measuring bacterial respiration (BR) during a lability incubation, which has been often applied in previous studies (del Giorgio and Cole, 1998; Jansson et al., 2000). The BR was determined by assessing decreases in dissolved oxygen concentrations in water samples from lakes $(n=13)$ and rivers $(n=8)$. Sample water was prepared in parallel with, and in the same way as, the $\mathrm{C}$ bioassays described above. Volumes of $0.5 \mathrm{~L}$ were added to glass incubation bottles (in duplicate) which had sensor spots affixed to the inside surface. Oxygen concentrations were measured in the dark every 5 min for up to 7 days with a FIBOX 3 (PreSens) that took optical readings from the outside of bioassay bottles. Estimates of BR were calculated from the averaged consumption of dissolved oxygen from the duplicate bottles by assuming a respiratory quotient of 1 , which is a conservative value for unproductive lakes (Berggren et al., 2012).

Bioavailable $\mathrm{N}$ was assessed using an alternative method described by Stepanauskas et al. (2000) by counting the cells produced in growth bioassays with N-starved bacteria. For this test, two aliquots of $30 \mathrm{~mL}$ were used for bioassays and one of them was amended with $\mathrm{N}-\mathrm{NH}_{4} \mathrm{NO}_{3}$ to a final concentration of $0.405 \mathrm{mg} \mathrm{N} \mathrm{L}^{-1}$. Both incubations were performed at $20^{\circ} \mathrm{C}$ degrees in the dark. Bacterial biomass was determined at the start of the incubation $(t=0)$ and after 3 days $(t=3)$ when the bacterial growth had peaked (Fig. 1). Bacterial samples were fixed with $3 \%(v / v)$ glutaraldehyde and kept at $5^{\circ} \mathrm{C}$ until analysis. Analyses of bacterial cells were conducted on a flow cytometer (FACScan, Becton Dickinson) on samples stained with SYTO 13 and run with the addition of beads as an internal standard according to del Giorgio et al. (1996), using CellQuest Pro software. Bacterial cells were distinguished based on green fluorescence intensity and side scatter signals. Total bacterial abundance was calculated as the sum of the populations that were distinguished in the cytograms. The $\mathrm{N}$ content per bacterial cell was determined by dividing the amount of $\mathrm{N}$ added to the amended aliquot by the difference in bacterial abundance between the $\mathrm{N}$-amended and the unamended aliquot. To obtain $\mathrm{BDN}$, the calculated average $\mathrm{N}$ content per cell was multiplied by the number of bacterial cells that were produced in the bioassay without addition. We validated our estimates of leucine incorporation per unit of bioavailable $\mathrm{P}$ by comparing it with the corresponding ratio in a completely independent boreal data set (Jansson et al., 2012). These independent data come from a freshwater study with near-identical bioassay conditions to those in our P bioassays, with the major difference being that Jansson et al. (2012) used larger incubation volumes $(>700 \mathrm{~mL})$ than we did when incubating in $1.5 \mathrm{~mL}$ Eppendorf tubes. Moreover, bioavailable $\mathrm{P}$ in the validation data was not assessed from bacterial growth data, but instead measured as $\mathrm{P}$ accumulation in bacterial cells harvested on filters. This is possible for P because standard TP methods provide high analytical precision at the microgram level (molybdenum blue method) that can resolve small changes in $\mathrm{P}$ concentration. Thus, we extracted the raw data from Jansson et al. (2012), in which both cumulative leucine incorporation and bioavailable $\mathrm{P}$ were quantified during the incubation of water from two northern Swedish streams sampled on six dates from late April to late October 2010. 


\subsection{Analytical methods and calculations}

Lake water chemistry was analysed at the department of Ecology and Environmental Science at Umeå University. Sample water for determination of DOC and TDN was filtered through a pre-ignited $\left(400^{\circ} \mathrm{C}, 3 \mathrm{~h}\right)$ acid-rinsed Whatman GF/F filters. The filtered water was acidified with $1.2 \mathrm{M} \mathrm{HCl}$ and analysed for DOC using a HACH-IL 550 TOC-TN. Filtered sample was analysed for TDN also using a HACH-IL 550 TOC-TN, while determination of nitrate $\left(\mathrm{NO}_{3}^{-}\right)$and ammonium $\left(\mathrm{NH}_{4}^{+}\right)$was done according to the International Organization for Standardisation (ISO) 133951996. Concentration of phosphate $\left(\mathrm{PO}_{4}-\mathrm{P}\right.$, assumed to be represented by soluble reactive $\mathrm{P}$ ) was determined from filtrates $(\mathrm{GF} / \mathrm{F})$ of water samples using the molybdate blue method (Murphy and Riley, 1962) and total phosphorus (TP) determined after oxidative hydrolysis with potassium persulfate (ISO 15861-1).

River DOC samples were filtered through a Whatman $\mathrm{GF} / \mathrm{F}$ filter into a pre-acid-washed $40 \mathrm{~mL}$ amber borosilicate vial, filled to the brim and tightly closed with silicon septa screw caps. Samples were kept cold in the fridge until analysis which took place at the G.G. Hatch Stable Isotope Laboratory, University of Ottawa. River samples for determination of (total dissolved nitrogen) TDN, $\mathrm{NO}_{3}^{-}, \mathrm{NH}_{4}^{+}$, TP, and $\mathrm{PO}_{4}-\mathrm{P}$ were frozen until analysis at the Evolutionary Biology Center, Uppsala University, following standard methods.

Our results provided estimates of total bioavailable resource pools. To calculate shares of bioavailable DON (BDON) and bioavailable DOP (BDOP), we subtracted the inorganic pools of DIN $\left(\mathrm{NO}_{3}^{-}, \mathrm{NH}_{4}^{+}\right)$, and $\mathrm{PO}_{4}-\mathrm{P}$ from the respective total bioavailable pools. Nutrient ratios were calculated in molar. We further calculated inorganic nutrient ratios of DIN to $\mathrm{PO}_{4}-\mathrm{P}\left(\mathrm{DIN}: \mathrm{PO}_{4}-\mathrm{P}\right)$.

\subsection{Statistical analyses}

Standard curves were fit by linear regressions using JMP 10 (SAS). Differences between the slopes of standard curves for each nutrient across lakes were tested by one-way analysis of variance (ANOVA, $p<0.05$ ) in SPSS 22.0 (SPSS Inc., Chicago, IL, USA). Since there were no statistical differences between the slopes for the four lakes for each resource (ANOVA, $p>0.44, n=20$ ), slopes were averaged for each nutrient across lakes. Differences between results of bioavailable resources across lakes and for each lake across time were tested using the Kruskal-Wallis $H$ test and Dunn's post-hoc test $(p<0.05)$ in SPSS. Differences between total and bioavailable resource ratios for the lakes were tested with dependent $t$ tests $(p=0.05)$ in SPSS. Previous work suggests that at higher DOM concentrations there is a greater discrepancy between bioavailable and total DOM fractions (Berggren et al., 2015). We therefore pooled the seven different rivers into two categories according to their DOC concentrations (3.7-23.0 $\mathrm{mg} \mathrm{C} \mathrm{L}^{-1}$ ); this resulted

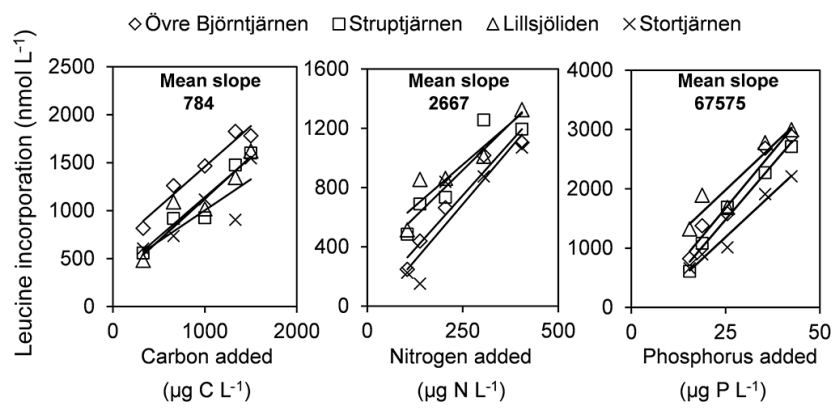

Figure 2. Measurements of leucine incorporation in relation to additions of bioavailable $\mathrm{C}$ (as $\left.\mathrm{C}_{6} \mathrm{H}_{12} \mathrm{O}_{6}\right), \mathrm{N}\left(\mathrm{NH}_{4} \mathrm{NO}_{3}\right.$ ), and $\mathrm{P}\left(\mathrm{Na}_{2} \mathrm{HPO}_{4}\right)$. Regression equations for all points pooled together: bioavailable $C=784 x+384\left(R^{2}=0.74, \quad p<0.0001\right.$; $n=20)$; bioavailable $N=2667 x+159\left(R^{2}=0.75, p<0.0001\right.$, $n=20)$; bioavailable $P=67575 x-110\left(R^{2}=0.80, p<0.0001\right.$, $n=20)$. Note that each individual regression line in the figure has a better fit than the regression line for all observations merged.

in an ensemble of three rivers which had DOC concentrations higher than $10 \mathrm{mg} \mathrm{CL}^{-1}$ (rivers $>10 \mathrm{mg} \mathrm{CL}^{-1}$ ) and four rivers that had DOC concentrations lower than $10 \mathrm{mg} \mathrm{C} \mathrm{L}^{-1}$ (rivers ${ }_{<10 \mathrm{mg} \mathrm{CL}^{-1}}$ ). Differences between total and bioavailable river nutrient ratios for the two groups were tested with dependent $t$ tests $(p=0.05)$ in SPSS.

\section{Results}

The rate of leucine incorporation increased over time in most bioassays until day $2(t=2)$, before gradually decreasing until day $7(t=7$; Fig. 1$)$. In the bioassays that were performed with resource additions, the accumulated leucine incorporation over the 7-day period was proportional to the concentrations of bioavailable resource added (Fig. 2). The results rendered an average linear relationship describing amounts of leucine incorporated per bioavailable $\mathrm{C}, \mathrm{N}$, and $\mathrm{P}$ (Fig. 2).

Bioavailable resource concentration spanned from 104 to $692 \mu \mathrm{g} \mathrm{CL}{ }^{-1}, 23$ to $287 \mu \mathrm{g} \mathrm{NL}^{-1}$, and 0 to $16 \mu \mathrm{g} \mathrm{PL}{ }^{-1}$ (Table 2). Concentrations of BDOC did not differ among lakes (ANOVA, $p>0.61, n=130$ ). By contrast, the four lakes did vary in average BDN and BDP (ANOVA, $p<0.05$, $n=130$ ). Lake Struptjärnen had on average the highest $\mathrm{BDN}$ and BDP concentrations $\left(159 \mu \mathrm{g} \mathrm{NL}^{-1} \pm 111 \mathrm{SE}\right.$ and $\left.8 \mu \mathrm{gPL}^{-1} \pm 4 \mathrm{SE}\right)$ and lake Lillsjöliden had the lowest values $\left(124 \mu \mathrm{g} \mathrm{NL}^{-1} \pm 97 \mathrm{SE}\right.$ and $\left.5 \mu \mathrm{gL}^{-1} \pm 3 \mathrm{SE}\right)$.

There was a significant difference in bioavailable resource concentrations over time across the lakes (ANOVA, $p<0.05, n=30-35$; Table 2). In general, concentrations of BDOC across the lakes were highest in October 2012 (mean $356 \mu \mathrm{gCL} \mathrm{CL}^{-1} \pm 84 \mathrm{SE}$ ) and lowest in August 2014 (mean $185 \mu \mathrm{g} \mathrm{CL}^{-1} \pm 59 \mathrm{SE}$ ), with a $33 \%$ difference in BDOC between maximum and minimum values during the studied period. Concentrations of BDN tended to be high in 
Table 2. (a) Bioavailable dissolved organic carbon, (b) bioavailable total nitrogen, and (c) bioavailable total phosphorus on seven sampling dates (columns). Values show means of five analytical replicates and standard deviations are provided within parentheses. Shared index letters within rows identify dates significantly different from each other $(p<0.05)$ which were determined by the Kruskal-Wallis $h$ and Dunn's post-hoc test.

\begin{tabular}{|c|c|c|c|c|c|c|c|}
\hline Lake & $\begin{array}{l}\text { Sep } \\
2012\end{array}$ & $\begin{array}{l}\text { Oct } \\
2012\end{array}$ & $\begin{array}{l}\text { Jul } \\
2013\end{array}$ & $\begin{array}{l}\text { Jun } \\
2014\end{array}$ & $\begin{array}{l}\text { Jul } \\
2014\end{array}$ & $\begin{array}{l}\text { Aug } \\
2014\end{array}$ & $\begin{array}{l}\text { Sep } \\
2014\end{array}$ \\
\hline \multicolumn{8}{|c|}{ (a) $\mathrm{BDOC}, \mu \mathrm{gLL}^{-1}$} \\
\hline Övre Björntjärnen & $\begin{array}{l}273^{a} \\
(143)\end{array}$ & & $\begin{array}{l}371^{\text {bcd }} \\
(64)\end{array}$ & $\begin{array}{l}420^{\text {aefg }} \\
(60)\end{array}$ & $\begin{array}{l}248^{\text {be }} \\
(39)\end{array}$ & $\begin{array}{l}243^{\mathrm{cf}} \\
(22)\end{array}$ & $\begin{array}{l}216^{\mathrm{dg}} \\
(21)\end{array}$ \\
\hline Lillsjöliden & $\begin{array}{l}471 \\
(435)\end{array}$ & $\begin{array}{l}552^{\mathrm{ab}} \\
(338)\end{array}$ & $\begin{array}{l}334^{\text {cde }} \\
(49)\end{array}$ & $\begin{array}{l}176^{\mathrm{ac}} \\
(36)\end{array}$ & $\begin{array}{l}205^{d} \\
(7)\end{array}$ & $\begin{array}{l}215 \\
(17)\end{array}$ & $\begin{array}{l}176^{\text {be }} \\
(36)\end{array}$ \\
\hline Struptjärnen & $\begin{array}{l}361^{a} \\
(327)\end{array}$ & & $\begin{array}{l}432^{b} \\
(93)\end{array}$ & $\begin{array}{l}692^{\text {acd }} \\
(85)\end{array}$ & $\begin{array}{l}337^{\mathrm{e}} \\
(27)\end{array}$ & $\begin{array}{l}178^{\mathrm{c}} \\
(21)\end{array}$ & $\begin{array}{l}107^{\text {bde }} \\
(6)\end{array}$ \\
\hline Stortjärnen & $\begin{array}{l}319^{a} \\
(210)\end{array}$ & $\begin{array}{l}428^{b} \\
(228)\end{array}$ & $\begin{array}{l}283^{c} \\
(49)\end{array}$ & $\begin{array}{l}301^{d} \\
(35)\end{array}$ & $\begin{array}{l}213^{e} \\
(15)\end{array}$ & $\begin{array}{l}104^{\mathrm{abcdf}} \\
(8)\end{array}$ & $\begin{array}{l}406^{\mathrm{ef}} \\
(130)\end{array}$ \\
\hline \multicolumn{8}{|c|}{ (b) $\mathrm{BDN}, \mu \mathrm{g} \mathrm{NL}^{-1}$} \\
\hline Övre Björntjärnen & $\begin{array}{l}209^{a b} \\
(13)\end{array}$ & & $\begin{array}{l}74^{\mathrm{c}} \\
(13)\end{array}$ & $\begin{array}{l}61^{a} \\
(6)\end{array}$ & $\begin{array}{l}84^{d} \\
(14)\end{array}$ & $\begin{array}{l}73^{\mathrm{e}} \\
(5)\end{array}$ & $\begin{array}{l}23^{\text {bcde }} \\
\text { (1) }\end{array}$ \\
\hline Lillsjöliden & $\begin{array}{l}287^{a b c} \\
(10)\end{array}$ & $\begin{array}{l}232^{\text {def }} \\
(24)\end{array}$ & $\begin{array}{l}111^{\mathrm{gh}} \\
(7)\end{array}$ & $\begin{array}{l}33^{\mathrm{adg}} \\
(10)\end{array}$ & $\begin{array}{l}64^{\text {be }} \\
(5)\end{array}$ & $\begin{array}{l}89^{a} \\
(6)\end{array}$ & $\begin{array}{l}51^{\mathrm{cfh}} \\
\text { (3) }\end{array}$ \\
\hline Struptjärnen & $\begin{array}{l}259^{a b c} \\
(6)\end{array}$ & & $\begin{array}{l}107^{\mathrm{ad}} \\
(28)\end{array}$ & $\begin{array}{l}220^{\mathrm{e}} \\
(14)\end{array}$ & $\begin{array}{l}273^{\mathrm{dfg}} \\
28\end{array}$ & $\begin{array}{l}60^{\mathrm{bf}} \\
(6)\end{array}$ & $\begin{array}{l}37^{\text {ceg }} \\
(2)\end{array}$ \\
\hline Stortjärnen & $\begin{array}{l}188^{a b} \\
(15)\end{array}$ & $\begin{array}{l}206^{\mathrm{cef}} \\
(18)\end{array}$ & $\begin{array}{l}82^{\mathrm{ac}} \\
(6)\end{array}$ & $\begin{array}{l}67^{\text {be }} \\
(5)\end{array}$ & $\begin{array}{l}84^{f} \\
(5)\end{array}$ & $\begin{array}{l}28^{\text {acfg }} \\
\text { (3) }\end{array}$ & $\begin{array}{l}119^{g} \\
(38)\end{array}$ \\
\hline \multicolumn{8}{|c|}{ (c) $\mathrm{BDP}, \mu \mathrm{g} \mathrm{PL}^{-1}$} \\
\hline Övre Björntjärnen & $9^{\mathrm{abc}}$ & & $5^{\mathrm{ad}}$ & $5^{\text {be }}$ & $9^{\text {def }}$ & $7^{g}$ & $3^{\mathrm{cfg}}$ \\
\hline & (1) & & $(0)$ & (0) & (1) & $(0)$ & $(0)$ \\
\hline Lillsjöliden & $\begin{array}{l}3^{a b} \\
(0)\end{array}$ & $\begin{array}{l}3^{c} \\
(0)\end{array}$ & $\begin{array}{l}2^{\text {def }} \\
(0)\end{array}$ & $\begin{array}{l}2^{\text {cgh }} \\
(0)\end{array}$ & $\begin{array}{l}10^{\text {acd }} \\
(2)\end{array}$ & $\begin{array}{l}7^{\text {beg }} \\
(1)\end{array}$ & $\begin{array}{l}6^{\text {fh }} \\
(0)\end{array}$ \\
\hline Struptjärnen & $\begin{array}{l}6^{\mathrm{ab}} \\
(1)\end{array}$ & & $\begin{array}{l}6^{\mathrm{c}} \\
(0)\end{array}$ & $\begin{array}{l}9^{\mathrm{ad}} \\
(1)\end{array}$ & $\begin{array}{l}16^{\text {bce }} \\
(2)\end{array}$ & $\begin{array}{l}7^{e} \\
(1)\end{array}$ & $\begin{array}{l}4^{\text {de }} \\
(0)\end{array}$ \\
\hline Stortjärnen & $\begin{array}{l}0^{\mathrm{ab}} \\
(0)\end{array}$ & $\begin{array}{l}0^{\text {cdef }} \\
(0)\end{array}$ & $\begin{array}{l}1^{\text {gh }} \\
(0)\end{array}$ & $\begin{array}{l}10^{\text {acg }} \\
(2)\end{array}$ & $\begin{array}{l}12^{\text {bdh }} \\
(2)\end{array}$ & $\begin{array}{l}6^{\mathrm{e}} \\
(0)\end{array}$ & $\begin{array}{l}5^{\mathrm{f}} \\
(2)\end{array}$ \\
\hline
\end{tabular}

September 2012 (mean of $236 \mu \mathrm{g} \mathrm{NL}^{-1} \pm 45 \mathrm{SE}$ ), lowest in September 2014 (mean of $58 \mu \mathrm{g} \mathrm{NL}^{-1} \pm 42 \mathrm{SE}$ ) and were $85 \%$ higher at its maximum compared to its minimum concentration. Concentrations of BDP were the highest in July 2014 (mean of $12 \mu \mathrm{gLL}^{-1} \pm 3 \mathrm{SE}$ ), lowest in October 2012 (mean of $4 \mu \mathrm{g} \mathrm{PL}{ }^{-1} \pm 3.6 \mathrm{SE}$ ) and varied approximately $83 \%$ throughout the studied period. There was no correlation between total and bioavailable element concentrations. Average fractions of bioavailable resources relative to the total pool were lowest for $\mathrm{C}$, highest for $\mathrm{P}$, and intermediate for N (Fig. 3). Organic forms were the major source of bioavailable resources for bacterioplankton, and represented $80 \%( \pm 13 \mathrm{SE})$ of the bioavailable $\mathrm{N}$ pool and $61 \%( \pm 46 \mathrm{SE})$ of the bioavailable P pool (Fig. 3). The contribution of inorganic fractions was therefore relatively more important for overall $\mathrm{P}$ than $\mathrm{N}$ bioavailability.
Molar nutrient ratios calculated for the total pool of nutrients were significantly higher than ratios calculated on the basis of the bioavailable fraction (dependent $t$ test, $p<0.05$, $n=26$; Fig. 4). For example, the average ratio of total $\mathrm{C}: \mathrm{N}$ was $55( \pm 9 \mathrm{SE})$ and was ca. 13 times higher than the $\mathrm{C}: \mathrm{N}$ bioavailable ratio which averaged 4 ( $\pm 3 \mathrm{SE}$ ). Similarly, average $\mathrm{C}: \mathrm{P}$ total ratio was $4774( \pm 2135 \mathrm{SE})$ and was 12 times significantly higher than the average bioavailable $\mathrm{C}: \mathrm{P}$ ratio 369 ( $\pm 915 \mathrm{SE})$. However, there were no significant differences (dependent $t$ test, $p>0.474, n=26$ ) between total $\mathrm{N}: \mathrm{P}$ ratios (average of $145 \pm 386 \mathrm{SE}$ ) and bioavailable $\mathrm{N}$ : $\mathrm{P}$ ratios (average of $89 \pm 44 \mathrm{SE}$ ), or between bioavailable $\mathrm{N}: \mathrm{P}$ ratios and the DIN : $\mathrm{PO}_{4}-\mathrm{P}$ ratio (mean of $29 \pm 19 \mathrm{SE}$; dependent $t$ test, $p>0.134, n=26$ ).

The amounts of leucine incorporated per unit of bioavailable resource in our growth bioassays (as determined by the slopes in Fig. 2) were validated by extracting the same ra- 

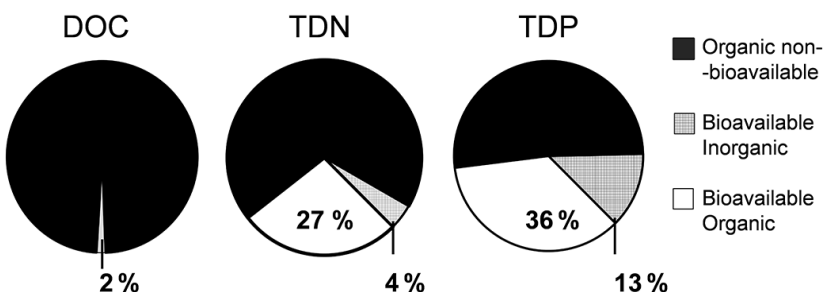

Figure 3. Proportion of organic non-bioavailable, organic bioavailable and inorganic nutrient shares of dissolved organic carbon (DOC), total dissolved nitrogen (TDN) and total phosphorus (TP) for all lakes and all sampling occasions $(n=26)$.

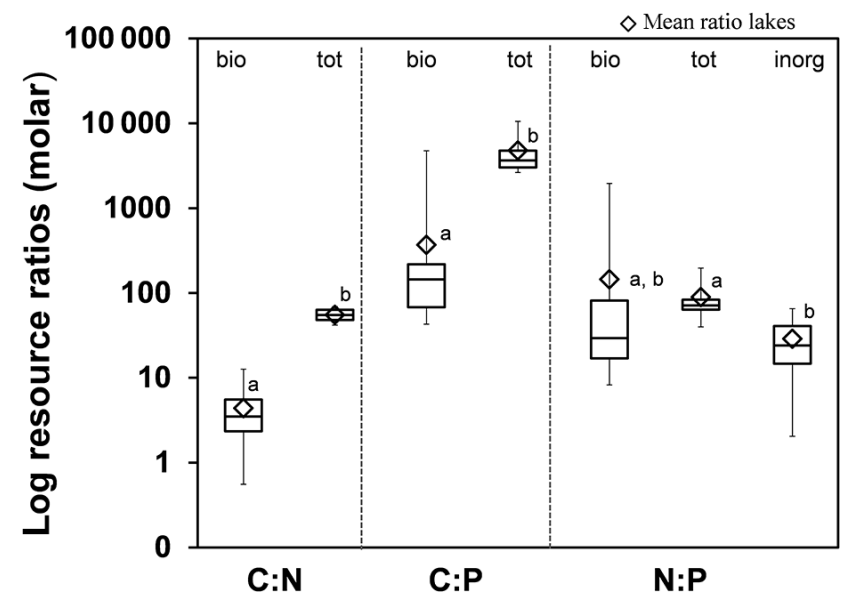

Figure 4. Bioavailable (bio) and total (tot) ratios (molar) of carbon to nitrogen $(\mathrm{C}: \mathrm{N})$ and carbon to phosphorus $(\mathrm{C}: \mathrm{P})$ for all lakes and all sampling dates $(n=26)$. Ratios of $\mathrm{N}: \mathrm{P}$ are shown for total, bioavailable, and inorganic (inorg) fractions. Different letters stand for significant differences (dependent $t$ test; $p<0.05 ; n=26$ ) among ratios. Data shown as box plots and includes mean as diamonds.

tio from the experiments performed using alternative bioassay methods (Fig. 5). The alternative bioassay methods were based on (1) inferring BDOC from bacterial respiration, (2) calculating BDN from cell yields, and (3) analysing BDP directly on the bacterial biomass (see methods). The growth responses (leucine incorporation) in our growth bioassays overlapped with the growth responses obtained from experiments using the alternative methods. However, on average the growth response was slightly higher in our bioassays compared to the alternative bioassays (Fig. 5).

For rivers, DOC appeared as the least bioavailable resource (in relation to the total pool) for both groups, rivers $_{>10 \mathrm{mg} \mathrm{CL}^{-1}}$ and rivers $<10 \mathrm{mg} \mathrm{CL}^{-1}$ (Table 3 ). In contrast, the BDN share was the most bioavailable with approximately half of the TN pool being bioavailable. Total nutrient ratios of $\mathrm{C}: \mathrm{N}$ and $\mathrm{C}: \mathrm{P}$ were statistically significantly higher (approximately 26- and 5-fold respectively) than the respective bioavailable resource ratios for rivers $>10 \mathrm{mg} \mathrm{CL}^{-1}$ (dependent $t$ test, $p<0.05, n=4)$. We found no differences between total $\mathrm{N}: \mathrm{P}$ ratio and bioavailable $\mathrm{N}: \mathrm{P}$ ratios, nor between each of

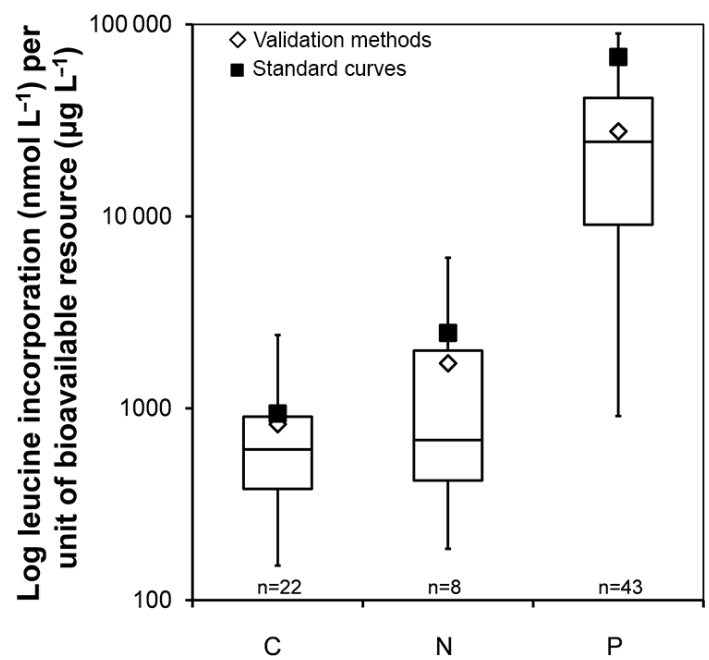

Figure 5. Log-scale box plots of incubation show leucine amounts per unit of bioavailable nutrient measured with validation methods: bacterial respiration $(\mathrm{C})$, cytometry $(\mathrm{N})$, and harvesting of cells in filters $(\mathrm{P})$. Diamonds are average values for the validation methods and filled squares are average slope values for standard curves (same values as slopes in Fig. 2).

Table 3. Resource bioavailability in relation to the total resource pool, shown as percent bioavailable dissolved organic carbon (BDOC), bioavailable dissolved nitrogen (BDN) and bioavailable dissolved phosphorus (BDP). The data are divided into two groups which show average results for rivers with more than $10 \mathrm{mg} \mathrm{C} \mathrm{L}^{-1}$ (rivers $>10 \mathrm{mgCL}^{-1} ; n=3$ ) and rivers with less than $10 \mathrm{mg} \mathrm{CL}^{-1}$ (rivers $<10 \mathrm{mg} \mathrm{CL}^{-1} ; n=4$ ). Average element ratios of carbon to nitrogen $(\mathrm{C}: \mathrm{N})$, carbon to phosphorus $(\mathrm{C}: \mathrm{P})$, nitrogen to phosphorus $(\mathrm{N}: \mathrm{P})$ are calculated in molar for total (tot) and bioavailable resource fractions (bio). Ratios of dissolved inorganic nitrogen to phosphate (DIN : $\left.\mathrm{PO}_{4}-\mathrm{P}\right)$ are also provided. Standard deviations are given within parentheses.

\begin{tabular}{lrr}
\hline Variable & rivers $_{>10 \mathrm{mg} \mathrm{CL}^{-1}}$ & rivers $_{<10 \mathrm{~m} \mathrm{CL}^{-1}}$ \\
\hline BDOC (\%) & $2(1)$ & $3(2)$ \\
BDN (\%) & $48(16)$ & $36(20)$ \\
BDP (\%) & $20(12)$ & $31(45)$ \\
C: (bio) & $1(1)$ & $2(1)$ \\
C:N (total) & $26(5)$ & $24(13)$ \\
C:P (bio) & $319(287)$ & $523(795)$ \\
C:P (total) & $1722(378)$ & $920(93)$ \\
N:P (bio) & $294(353)$ & $240(251)$ \\
N:P (tot) & $70(27)$ & $46(21)$ \\
DIN: PO $_{4}-\mathrm{P}$ & $88(68)$ & $2(2)$ \\
\hline
\end{tabular}

these and DIN : $\mathrm{PO}_{4}-\mathrm{P}$ ratios for both rivers $>10 \mathrm{mgCL}^{-1}$ (dependent $t$ test, $p>0.07, n=4$ ) and rivers $<10 \mathrm{mgCL}^{-1}$ (dependent $t$ test, $p>0.10, n=3$ ). 


\section{Discussion}

\subsection{Resource bioavailability as a driver of ecological patterns}

Results from this study underscore the ineffectiveness of total nutrient fractions as predictors of bioavailability in boreal freshwater ecosystems. In these aquatic systems that have high absolute concentrations of DOC, $\mathrm{C}$ bioavailability was lowest relative to $\mathrm{N}$ and $\mathrm{P}$. This study not only reveals the likely control that $\mathrm{C}$ has on boreal heterotrophic aquatic metabolism but also suggests that possible changes in $\mathrm{C}$ loading of the boreal water systems in the future may impact aquatic productivity and the turnover of nutrients. Northern catchments are thought to be particularly sensitive to ongoing climate change (Tetzlaff et al., 2013) and this refined understanding of bioavailable resource stoichiometry may be essential to forecast and mitigate aquatic ecosystem responses to these and other anthropogenic pressures at high latitudes.

\subsection{Bioavailable concentrations of DOC, TDN, and TDP in lakes}

Our estimates, which reflect the resource pool readily available to bacterioplankton at any point in time, supported our expectations by showing that nutrient bioavailability (as percentage of the total pool), increased from BDOC to BDN and from BDN to BDP. The observed differences in $\mathrm{N}$ and $\mathrm{P}$ bioavailability match the overall trend reported for aquatic ecosystems in the literature (Berggren et al., 2015) and are generally consistent with our understanding of how these elements are bound to organic matter. Organic $\mathrm{N}$ tends to form covalent bonds directly to $\mathrm{C}$ and may be physically and chemically protected within complex, organic compounds that are resistant to decay (Schulten and Schnitzer, 1997). Liberating this $\mathrm{N}$ is linked to organic matter depolymerisation and $\mathrm{C}$ mineralisation (Schimel and Bennett, 2004), requiring multiple exo-enzymatic steps that are energetically expensive (Sinsabaugh and Follstad, 2011). By contrast, organic $\mathrm{P}$ is more often associated with ester bonds (C-O-P) that can be cleaved in a single enzymatic step independent of C mineralisation (McGill and Cole, 1981). In addition, other forms of inorganic P (e.g. orthophosphate) may be only loosely bound and exchanging with iron-humic complexes (Jones, 1998). These binding properties are thought to govern differences in the relative rates of $\mathrm{N}$ and $\mathrm{P}$ cycling in soils (Vitousek et al., 2002) and our results suggest that the same factors may shape the relative bioavailability of these resources in freshwater environments as well.

The method we describe here generated simultaneous bioavailability estimates for $\mathrm{C}, \mathrm{N}$, and $\mathrm{P}$ that were comparable to those from single-element bioassays reported elsewhere. Absolute concentrations of BDOC (100$690 \mu \mathrm{CL}^{-1}$ ) were within the range of reported values for cedar bog wetlands $\left(12-408 \mu \mathrm{gCL}^{-1}\right.$; Wiegner and
Seitzinger, 2004) and were at the lower end of values reported for rivers (108-180 $\mu \mathrm{g} \mathrm{CL}^{-1}$; Wiegner et al., 2006). Concentrations of BDN $\left(30-320 \mu \mathrm{g} \mathrm{NL}^{-1}\right)$ were in agreement with bioavailable $\mathrm{N}$ concentrations reported for cedar bog wetlands $\left(0-322 \mu \mathrm{g} \mathrm{NL}{ }^{-1}\right.$; Wiegner and Seitzinger, 2004). BDP (0-16 $\left.\mu \mathrm{g} \mathrm{PL}^{-1}\right)$ was comparable to values from a recent study on headwater streams during low flow (1$14 \mu \mathrm{g} \mathrm{PL}^{-1}$; Jansson et al., 2012). In addition, organic forms dominated the total bioavailable $\mathrm{N}$ and $\mathrm{P}$ pool (80 and 61\%) in our four lakes, and 27 and $36 \%$ of these organic pools were bioavailable for $\mathrm{N}$ and $\mathrm{P}$ respectively. These results are in line with previous estimates and show that a large fraction of DON is available to bacterioplankton in diverse limnetic systems, e.g. in Baltic Sea rivers (30\%; Stepanauskas et al., 2002), in eastern US rivers (23\%; Wiegner et al., 2006) and in cedar bog wetland streams (33\%; Wiegner and Seitzinger, 2004). Published estimates of the share of BDOP (bioavailable dissolved organic phosphorus) relative to the total DOP pool varied from 33 to $60 \%$ in Baltic Sea brackish waters (Nausch and Nausch, 2007). Thus, our results agree with the results from previous studies and together they emphasise the importance of organic nutrient fractions in systems rich in organic matter as well as the capacity of bacterioplankton to take up organic compounds.

Concentrations of BDOC, BDN and BDP varied seasonally in all lakes during the study period (Table 2). Major differences in BDOC were observed between midsummer, when concentrations were lowest, and the end of the summer, when concentrations were high. Previous experimental work on boreal and arctic rivers has also shown minimal concentrations of BDOC during the summer season (Wickland et al., 2012). In addition, concentrations of BDOC tended to follow bulk DOC concentrations in boreal freshwater systems as suggested in Søndergaard and Middelboe (1995). By contrast, patterns of BDP concentrations opposed those of BDOC (Table 2): specifically, BDP peaked in midsummer (July) and declined in the autumn. It has been shown elsewhere that bioavailable $\mathrm{P}$ concentrations in boreal streams can be $2-10$ times higher during summer than during autumn (Jansson et al., 2012). This may be due to higher soil temperatures during summer which promote soil $\mathrm{C}$ metabolism and result in a higher export of $\mathrm{P}$ from soils to surface waters compared to that of C (Jansson et al., 2012).

Our results also supported the prediction that the bioavailable ratios of $\mathrm{C}: \mathrm{N}$ and $\mathrm{C}: \mathrm{P}$ would be considerably lower than their counterparts based on total pools. A major implication of these differences is that ratios based on total pools grossly overestimate actual $\mathrm{C}$ availability. When such differences are large, the elemental ratios based on total pools can lead to incorrect predictions of resource limitation (Berggren et al., 2015). For example, in a recent study of two temperate estuaries, total resource stoichiometry predicted $\mathrm{P}$ limitation of bacterioplankton, while experimental evidence showed that $\mathrm{C}$ was the element constraining bacterial growth during base flow (Hitchcock and Mitrovic, 2013). Average 
DIN : $\mathrm{PO}_{4}-\mathrm{P}$ ratios and particularly total TN : TP were however, closer to the average ratio of bioavailable TN: TP. Due to the high $\mathrm{C}$ recalcitrance, nutrient limitation predictions based on the ratio of total resource pools may be inadequate when $\mathrm{C}$ is included in the ratio, but seem more promising when based on $\mathrm{N}$ and $\mathrm{P}$.

Our results further show that while the median bulk stoichiometric ratio (3651C: $71 \mathrm{~N}$ : 1P; Fig. 4) was 1-2 orders of magnitude higher than that expected from the Redfield ratio (106C:16N:1P; Anderson, 1995; Redfield, 1958), the median $C: N: P$ of bioavailable resources $(144 \mathrm{C}: 29 \mathrm{~N}: 1 \mathrm{P})$ was surprisingly comparable yet slightly above Redfield values (Fig. 4). There was, however, a wide variability in the bioavailable ratios among samples collected over space and time. Such variance is consistent with another study that evaluated bacterial stoichiometry across a large number of lakes and showed that, while elemental stoichiometry varied among lakes in response to intrinsic and extrinsic factors, the overall mean ratio tended to converge with Redfield (Cotner et al., 2010).

\subsection{Broad-scale riverine BDOC, BDN and BDP patterns}

Broad-scale patterns of nutrient bioavailability at the river mouths did not differ between rivers $<10 \mathrm{mgCL}^{-1}$ and rivers $>10 \mathrm{mg} \mathrm{CL}^{-1}$. Similar to what was observed in the lakes, DOC was the most recalcitrant nutrient considered. However, in contrast to our results from the lakes, TDN was the most bioavailable resource observed in the river mouths (Table 3). Although previous studies suggest that temperature differences across catchments can influence $\mathrm{C}: \mathrm{N}$ ratios in streams and rivers through effects on terrestrial ecosystem properties (e.g. vegetation type) and soil development (Sponseller et al., 2014), our results show a similar bioavailable resource stoichiometry at the outlet of all these rivers. Organic forms of $\mathrm{N}$ were a major source of bioavailability and dominated TDN, in agreement with estimates from other studies (Wiegner et al., 2006; Seitzinger and Sanders, 1997; Stepanauskas et al., 2002). Significant differences between total and bioavailable $\mathrm{C}: \mathrm{N}$ and $\mathrm{C}: \mathrm{P}$ ratios occurred only in rivers $>10 \mathrm{mg} \mathrm{CL}^{-1}$. However, neither rivers $>10 \mathrm{mg} \mathrm{CL}^{-1}$ nor rivers $<10 \mathrm{mg} \mathrm{CL}^{-1}$ showed differences between total $\mathrm{N}: \mathrm{P}$, bioavailable $\mathrm{N}: \mathrm{P}$ and $\mathrm{DIN}: \mathrm{PO}_{4}^{3-}$ ratios. These results indicate that, similar to the patterns observed in lakes, the use of bulk resource ratios misrepresents resource bioavailability and limitation when (1) $\mathrm{C}$ is part of the nutrient ratio and (2) there is a high concentration of DOC in the water.

While Swedish rivers have substantial water renewal along watercourses from the Scandes to the Baltic Sea (Muller et al., 2013), at such broad scales several environmental factors may modify element bioavailability through modification and differential uptake and remineralisation of $\mathrm{C}, \mathrm{N}$, and P. For example, bacterial processing (Creed et al., 2015), photodegradation (Bushaw et al., 1996) and reactive oxygen
(Gao and Zepp, 1998) may influence organic matter degradation and changes in bioavailability over the long timescales encompassed by large river systems. In this regard, it is interesting to note that our estimates of short-term macro-nutrient bioavailability were similar for lakes and rivers, which suggest that possible differences in long-term macronutrient bioavailability across these very different sites did not seem to impact on the results determined under our specific laboratory conditions. The general pattern that we found across all sites was a relatively low bioavailability of $\mathrm{C}$ relative to that of $\mathrm{N}$ and $\mathrm{P}$. This may suggest that $\mathrm{C}$ is more important as limiting factor for bacterial metabolism than previously thought. However, while our results directly provide information on the maximal pools of bioavailable macronutrients that can be readily consumed, the true exploitation of these resources in nature is dependent on other (extrinsic) factors such as microelement limitation, element co-limitation, and grazing pressures. Thus, based on our result alone it is not possible to determine whether or not the in situ bacterial metabolism was limited by a specific macronutrient, although it appears more likely that $\mathrm{C}$ would be limiting than $\mathrm{N}$ or $\mathrm{P}$.

\subsection{Measuring bioavailability of $\mathrm{C}, \mathrm{N}$, and $\mathrm{P}$ with leucine incorporation}

The linear relationships obtained from standard growth curves relating leucine incorporation to bioavailable resource concentrations showed that incorporation over a 7-day period was significantly and positively related to the amount of resource added. The fact that these relationships were not statistically different between the lakes suggests that leucine incorporation was driven by the added resources rather than other factors that could have affected the experiment. For example, variations in lake $\mathrm{pH}$ could have impacted the amount of resources taken up in the bioassays (del Giorgio and Davis 2003; Li et al., 2012). Due to the lack of replication of standard river curves, we could not test whether or not the standard curves of individual rivers were also similar to those of lakes. However, we suspect that physical and chemical water sample properties may differentially influence leucine uptake in different systems. Our blank bioassays further confirmed the dependency between leucine incorporation and limiting resource concentration by showing that virtually no leucine incorporation occurred when the limiting resource was lacking in the growth media.

We used the leucine incorporation method as a proxy for bacterial growth and related it to bioavailable resource concentrations based on the premise that this process measures the rate of bacterial protein synthesis (Kirchman et al., 1985). Because proteins are large macromolecules within bacterial cells (approximately half of bacterial dry weight), they represent a substantial fraction of the resource uptake and its consequent conversion into biomass. Also, to carry out protein synthesis, bacteria use both $\mathrm{C}$ and $\mathrm{N}$; nitrogenous compounds are taken up from the growth medium to build proteins with 
energy obtained from C substrates. Phosphorus is also used in the process as it is crucial for controlling the adenosine triphosphate-adenosine diphosphate cycle, which provides energy for the intracellular molecular synthesis. Due to the critical role that these three elements play within protein synthesis, our results represent an unequivocal relationship between resource availability and the amount of protein synthesised. We measured resource bioavailability over a time period of 7 days and the major part of the resource pool was exhausted within 3 days (Fig. 1). In the context of bioavailability assessments, 7 days is a relatively short period and repeated bacterial regeneration of resources was avoided in this way (Cho et al., 1996). Although there may have been some resource recycling, our bioavailability estimates are automatically corrected for this artefact as these were calculated based on standard curves for leucine incorporation per absolute unit of added bioavailable resource, constructed for the exact same time period.

The design of our experiment could lead to possible sources of errors in estimates. For example, reference assays (standard curves) were performed on one occasion and used to interpret actual nutrient bioavailability on other occasions. This means that if BGE varied during the studied period it could result in differences in the amounts of leucine incorporated. We dealt with this possible shortcoming by designing our bioassays such that resource use efficiency would be maximised (by strongly inducing resource limitation; Jansson et al., 2006) and thus, possible variations in resource use efficiency most likely did not play a substantial role on rates of leucine uptake (Fig. 5). In addition, the fact that glucose was used as the reference source of $\mathrm{C}$ and energy in the calibration could lead to an overestimation of the standard $\mathrm{C}$ growth curves and possibly result in conservative estimates of bioavailable C. For example, glucose additions could have supported the part of the community with the fastest growth and therefore results may not compare to results from a community that was instead exposed to a natural substrate. Nonetheless, when comparing the amount of leucine incorporated by our standard bacterial community per unit of bioavailable glucose with amounts of leucine incorporated per unit of natural bioavailable substrate (Fig. 5), we show that, on average, our growth response was only slightly higher than the growth response in experiments based on alternative bioassay methods (Fig. 5). Thus, our resource bioavailable estimates presented here are most likely conservative but realistic.

\section{Conclusions}

Ongoing changes in the global $\mathrm{C}, \mathrm{N}$, and $\mathrm{P}$ cycles have the capacity to modify the chemical conditions and nutrient balance of receiving waters (Finzi et al., 2011). Yet the effects of these changes on basal productivity and food webs of many inland waters remain difficult to predict. We suggest that to better forecast the impact of such changes, it is important that we refine how we consider and measure the stoichiometry of the main elements available to support aquatic production. This study contributes to our general understanding of resource dynamics in DOM-rich systems. Based on bioavailable resource ratios determined with a single approach, we show that resource bioavailability increases from $\mathrm{C}$ to $\mathrm{N}$ and $\mathrm{N}$ to $\mathrm{P}$. P availability in these systems may, thus, be likely considerably higher than previously thought. This finding particularly calls into question whether results from most enrichment experiments done so far, which often show that $\mathrm{P}$ additions stimulate BP, are applicable to DOM-rich systems (Jansson et al., 2001). In addition, our findings reinforce the idea that, despite boreal waters being DOM-rich, the $\mathrm{C}$ availability of humic waters is extremely low. This means that expected future changes in the amount or character of $\mathrm{C}$ delivered to boreal surface waters will most likely drive changes in BP, which subsequently affects abiotic conditions, the biotic structure, and ecosystem functioning of freshwaters.

Data availability. The data used and generated in this study are available from the corresponding author upon request.

\section{The Supplement related to this article is available online at doi:10.5194/bg-14-1527-2017-supplement.}

Competing interests. The authors declare that they have no conflict of interest.

Acknowledgements. The authors thank Anders Jonsson, Juan Pablo Niño, Karla Münzer, Julia Jakobsson and Lina Allesson for providing help with the sample analysis. We also thank Anne Deininger and Marcus Klaus for help with lake water sampling and shipping. Ana R. A. Soares would like to acknowledge the ClimBEco Graduate School for funding a research visit. The Crafoord Foundation (grant \#20120626), KSLA (grant \#H130020-GBN), FORMAS (grant \#217-2010-126), and Helge Ax:son Johnson's Foundation (grant \#140622) contributed by funding the study via Martin Berggren. Reiner Giesler was supported by The Carl Trygger Foundation for Scientific Research (grant \#CTS12:147) and Ann-Kristin Bergström by FORMAS (grant \#215-2010-992).

Edited by: B. A. Pellerin

Reviewed by: two anonymous referees

\section{References}

Anderson, L. A.: On the hydrogen and oxygen-content of marine phytoplankton, Deep-Sea Res. Pt. I, 42, 1675-1680, 1995.

Battin, T. J., Kaplan, L. A., Findlay, S., Hopkinson, C. S., Marti, E., Packman, A. I., Newbold, J. D., and Sabater, F.: Biophysical con- 
trols on organic carbon fluxes in fluvial networks, Nat. Geosci., 1, 95-100, doi:10.1038/ngeo101, 2008.

Berggren, M., Lapierre, J. F., and Del Giorgio, P. A.: Magnitude and regulation of bacterioplankton respiratory quotient across freshwater environmental gradients, ISME J., 6, 984-993, 2012.

Berggren, M., Sponseller, R. A., Soares, A. R. A., and Bergstrom, A. K.: Toward an ecologically meaningful view of resource stoichiometry in DOM-dominated aquatic systems, J. Plankton Res., 37, 489-499, doi:10.1093/plankt/fbv018, 2015.

Bronk, D. A., See, J. H., Bradley, P., and Killberg, L.: DON as a source of bioavailable nitrogen for phytoplankton, Biogeosciences, 4, 283-296, doi:10.5194/bg-4-283-2007, 2007.

Bushaw, K. L., Zepp, R. G., Tarr, M. A., SchulzJander, D., Bourbonniere, R. A., Hodson, R. E., Miller, W. L., Bronk, D. A., and Moran, M. A.: Photochemical release of biologically available nitrogen from aquatic dissolved organic matter, Nature, 381, 404-407, 1996.

Cho, B. C., Park, M. G., Shim, J. H., and Azam, F.: Significance of bacteria in urea dynamics in coastal surface waters, Mar. Ecol.Prog. Ser., 142, 19-26, doi:10.3354/meps142019, 1996.

Cotner, J. B., Hall, E. K., Scott, J. T., and Heldal, M.: Freshwater bacteria are stoichiometrically flexible with a nutrient composition similar to seston, Front. Microbiol., 1, 132, doi:10.3389/fmicb.2010.00132, 2010.

Creed, I. F., McKnight, D. M., Pellerin, B. A., Green, M. B., Bergamaschi, B. A., Aiken, G. R., Burns, D. A., Findlay, S. E. G., Shanley, J. B., Striegl, R. G., Aulenbach, B. T., Clow, D. W., Laudon, H., McGlynn, B. L., McGuire, K. J., Smith, R. A., and Stackpoole, S. M.: The river as a chemostat: fresh perspectives on dissolved organic matter flowing down the river continuum, Can. J. Fish. Aquat. Sci., 72, 1272-1285, doi:10.1139/cjfas2014-0400, 2015.

del Giorgio, P. A., Bird, D. F., Prairie, Y. T., and Planas, D.: Flow cytometric determination of bacterial abundance in lake plankton with the green nucleic acid stain SYTO 13, Limnol. Oceanogr., 41, 783-789, 1996.

del Giorgio, P. A. and Cole, J. J.: Bacterial growth efficiency in natural aquatic systems, Annu. Rev. Ecol. Syst., 29, 503-541, 1998.

del Giorgio, P. A. and Davis, J.: Patterns in dissolved organic matter lability and consumption across aquatic ecosystems, in: Aquatic ecosystems: Interactivity of dissolved organic matter, edited by: Findlay, S. E. G. and Sinsabaugh, R. L., Academic Press, 399424, 2003

Dillon, P. J. and Molot, L. A.: Long-term trends in catchment export and lake retention of dissolved organic carbon, dissolved organic nitrogen, total iron, and total phosphorus: The Dorset, Ontario, study, 1978-1998, J. Geophys. Res.-Biogeo., 110, G01002, doi:10.1029/2004jg000003, 2005.

Finzi, A. C., Cole, J. J., Doney, S. C., Holland, E. A., and Jackson, R. B.: Research frontiers in the analysis of coupled biogeochemical cycles, Front. Ecol. Environ., 9, 74-80, doi:10.1890/100137, 2011.

Gao, H. Z. and Zepp, R. G.: Factors influencing photoreactions of dissolved organic matter in a coastal river of the southeastern United States, Environ. Sci. Technol., 32, 2940-2946, doi:10.1021/es9803660, 1998.

Helton, A. M., Wright, M. S., Bernhardt, E. S., Poole, G. C., Cory, R. M., and Stanford, J. A.: Dissolved organic carbon lability in- creases with water residence time in the alluvial aquifer of a river floodplain ecosystem, J. Geophys. Res.-Biogeo., 120, 693-706, doi:10.1002/2014jg002832, 2015.

Hitchcock, J. N. and Mitrovic, S. M.: Different resource limitation by carbon, nitrogen and phosphorus between base flow and high flow conditions for estuarine bacteria and phytoplankton, Estuar. Coast. Shelf Sci., 135, 106-115, doi:10.1016/j.ecss.2013.05.001, 2013.

Jansson, M.: Nutrient limitation and bacteria-phytoplankton interactions in humic lakes, in: Aquatic humic substances: ecology and biogeochemistry, edited by: Tranvik, L. J. and Hessen, D. O., Springer-Verlag, Berlin, 177-196, 1998.

Jansson, M., Bergström, A. K., Blomqvist, P., and Drakare, S.: Allochthonous organic carbon and phytoplankton/bacterioplankton production relationships in lakes, Ecology, 81, 3250-3255, 2000.

Jansson, M., Bergström, A. K., Drakare, S., and Blomqvist, P.: Nutrient limitation of bacterioplankton and phytoplankton in humic lakes in northern Sweden, Freshwater Biol., 46, 653-666, 2001.

Jansson, M., Bergström, A. K., Lymer, D., Vrede, K., and Karlsson, J.: Bacterioplankton growth and nutrient use efficiencies under variable organic carbon and inorganic phosphorus ratios, Microb. Ecol., 52, 358-364, 2006.

Jansson, M., Berggren, M., Laudon, H., and Jonsson, A.: Bioavailable phosphorus in humic headwater streams in boreal Sweden, Limnol. Oceanogr., 57, 1161-1170, 2012.

Jones, D. L.: Organic acids in the rhizosphere - a critical review, Plant Soil, 205, 25-44, 1998.

Karlsson, J., Jansson, M., and Jonsson, A.: Similar relationships between pelagic primary and bacterial production in clearwater and humic lakes, Ecology, 83, 2902-2910, 2002.

Karlsson, J., Berggren, M., Ask, J., Byström, P., Jonsson, A., Laudon, H., and Jansson, M.: Terrestrial organic matter support of lake food webs: Evidence from lake metabolism and stable hydrogen isotopes of consumers, Limnol. Oceanogr., 57, 1042 1048, 2012.

Kirchman, D., Knees, E., and Hodson, R.: Leucine incorporation and its potential as a measure of protein-synthesis by bacteria in natural aquatic systems, Appl. Environ. Microbiol., 49, 599-607, 1985.

Laudon, H., Taberman, I., Agren, A., Futter, M., OttossonLofvenius, M., and Bishop, K.: The Krycklan Catchment StudyA flagship infrastructure for hydrology, biogeochemistry, and climate research in the boreal landscape, Water Resour. Res., 49, 7154-7158, doi:10.1002/wrcr.20520, 2013.

Lewis Jr., W. M.: Rationale for control of anthropogenic nitrogen and phosphorus to reduce eutrophication of inland waters, Environ. Sci. Technol., 45, 10300-5, doi:10.1021/es202401p, 2011.

Li, Y., Yu, S., Strong, J., and Wang, H.: Are the biogeochemical cycles of carbon, nitrogen, sulfur, and phosphorus driven by the "FeIII-FeII redox wheel" in dynamic redox environments?, J Soil. Sediment., 12, 683-693, doi:10.1007/s11368-012-0507-z, 2012.

Lindström, K.: Nutrient requirements of the dinoflagellate Peridinium gatunense, J. Phycol., 27, 207-219, 1991.

Lonborg, C. and Anton Alvarez-Salgado, X.: Recycling versus export of bioavailable dissolved organic matter in the coastal ocean and efficiency of the continental shelf pump, Global Biogeochem. Cy., 26, GB3018, doi:10.1029/2012gb004353, 2012. 
Martinez, J., Smith, D. C., Steward, G. F., and Azam, F.: Variability in ectohydrolytic enzyme activities of pelagic marine bacteria and its significance for substrate processing in the sea, Aquat. Microb. Ecol., 10, 223-230, 1996.

McGill, W. B., and Cole, C. V.: Comparative Aspects Of Cycling Of Organic C, N, S And P Through Soil Organic-Matter, Geoderma, 26, 267-286, doi:10.1016/0016-7061(81)90024-0, 1981.

Muller, R. A., Futter, M. N., Sobek, S., Nisell, J., Bishop, K., and Weyhenmeyer, G. A.: Water renewal along the aquatic continuum offsets cumulative retention by lakes: implications for the character of organic carbon in boreal lakes, Aquat. Sci., 75, 535545, doi:10.1007/s00027-013-0298-3, 2013.

Murphy, J. and Riley, J. P.: A modified single solution method for the determination of phosphate in natural waters, Anal. Chim. Acta, 27, 31-36, 1962.

Muscarella, M. E., Bird, K. C., Larsen, M. L., Placella, S. A., and Lennon, J. T.: Phosphorus resource heterogeneity in microbial food webs, Aquat. Microb. Ecol., 73, 259-272, doi:10.3354/ame01722, 2014.

Nausch, M. and Nausch, G.: Bioavailable dissolved organic phosphorus and phosphorus use by heterotrophic bacteria, Aquat. Biol., 1, 151-160, doi:10.3354/ab00012, 2007.

Pellerin, B. A., Kaushal, S. S., and McDowell, W. H.: Does anthropogenic nitrogen enrichment increase organic nitrogen concentrations in runoff from forested and human-dominated watersheds?, Ecosystems, 9, 852-864, doi:10.1007/s10021-006-00763, 2006.

Redfield, A. C.: The biological control of chemical factors in the environment, Am. Scientist, 46, 205-221, 1958.

Schimel, J. P. and Bennett, J.: Nitrogen mineralization: Challenges of a changing paradigm, Ecology, 85, 591-602, doi:10.1890/038002, 2004.

Schulten, H. R. and Schnitzer, M.: The chemistry of soil organic nitrogen: a review, Biol. Fertil. Soils, 26, 1-15, doi:10.1007/s003740050335, 1997.

Seitzinger, S. P. and Sanders, R. W.: Contribution of dissolved organic nitrogen from rivers to estuarine eutrophication, Mar. Ecol.-Prog. Ser., 159, 1-12, doi:10.3354/meps159001, 1997.

Seitzinger, S. P., Sanders, R. W., and Styles, R.: Bioavailability of DON from natural and anthropogenic sources to estuarine plankton, Limnol. Oceanogr., 47, 353-366, 2002.

Sinsabaugh, R. L. and Shah, J. J. F.: Ecoenzymatic stoichiometry of recalcitrant organic matter decomposition: the growth rate hypothesis in reverse, Biogeochemistry, 102, 31-43, doi:10.1007/s10533-010-9482-x, 2011.

Smith, D. C. and Azam, F.: A simple, economical method for measuring bacterial protein synthesis rates in seawater using $3 \mathrm{H}$ leucine, Marine Microbial Food Webs, 6, 107-114, 1992.
Søndergaard, M. and Middelboe, M.: A cross-system analysis of labile dissolved organic carbon, Mar. Ecol.-Prog. Ser., 118, 283294, 1995.

Sponseller, R. A., Temnerud, J., Bishop, K., and Laudon, H.: Patterns and drivers of riverine nitrogen $(\mathrm{N})$ across alpine, subarctic, and boreal Sweden, Biogeochemistry, 120, 105-120, doi:10.1007/s10533-014-9984-z, 2014.

Stepanauskas, R., Leonardson, L., and Tranvik, L. J.: Bioavailability of wetland-derived DON to freshwater and marine bacterioplankton, Limnol. Oceanogr., 44, 1477-1485, 1999.

Stepanauskas, R., Laudon, H., and Jorgensen, N. O. G.: High DON bioavailability in boreal streams during a spring flood, Limnol. Oceanogr., 45, 1298-1307, 2000.

Stepanauskas, R., Jørgensen, N. O. G., Eigaard, O. R., Zvikas, A., Tranvik, L. J., and Leonardson, L.: Summer inputs of riverine nutrients to the Baltic Sea: Bioavailability and eutrophication relevance, Ecol. Monogr., 72, 579-597, doi:10.2307/3100058, 2002.

Tetzlaff, D., Soulsby, C., Buttle, J., Capell, R., Carey, S. K., Laudon, H., McDonnell, J., McGuire, K., Seibert, S., and Shanley, J.: Catchments on the cusp? Structural and functional change in northern ecohydrology, Hydrol. Process., 27, 766-774, doi:10.1002/hyp.9700, 2013.

Tranvik, L. J.: Availability of dissolved organic carbon for planktonic bacteria in oligotrophic lakes of differing humic content, Microb. Ecol., 16, 311-322, 1988.

Tranvik, L. J.: Degradation of dissolved organic matter in humic waters by bacteria, in: Ecological Studies; Aquatic humic substances: Ecology and biogeochemistry, edited by: Hessen, D. O. and Tranvik, L. J., Ecological Studies, Springer-Verlag, Heidelberger Platz 3, D-1000 Berlin, Germany 175 Fifth Avenue, New York, New York 10010, USA, 259-283, 1998.

Vitousek, P. M., Hattenschwiler, S., Olander, L., and Allison, S.: Nitrogen and nature, Ambio, 31, 97-101, doi:10.1639/00447447(2002)031[0097:nan]2.0.co;2, 2002.

Wetzel, R. G.: Limnology: Lake and river ecosystems, 3rd edn., Academic Press, San Diego, 1006 pp., 2001.

Wickland, K. P., Aiken, G. R., Butler, K., Dornblaser, M. M., Spencer, R. G. M., and Striegl, R. G.: Biodegradability of dissolved organic carbon in the Yukon River and its tributaries: Seasonality and importance of inorganic nitrogen, Global Biogeochem. Cy., 26, Gb0e03, doi:10.1029/2012gb004342, 2012.

Wiegner, T. N. and Seitzinger, S. P.: Seasonal bioavailability of dissolved organic carbon and nitrogen from pristine and polluted freshwater wetlands, Limnol. Oceanogr., 49, 1703-1712, 2004.

Wiegner, T. N., Seitzinger, S. P., Glibert, P. M., and Bronk, D. A.: Bioavailability of dissolved organic nitrogen and carbon from nine rivers in the eastern United States, Aquat. Microb. Ecol., 43, 277-287, 2006. 